\title{
PENERAPAN AKUNTANSI DAN KESESUAIANNYA DENGAN SAK ETAP PADA UMKM KOTA TEGAL
}

\author{
Hetika $^{1)}$, Nurul Mahmudah ${ }^{2)}$ \\ 1,2) Politeknik Harapan Bersama \\ ${ }^{1)}$ hetika.maksi@gmail.com, ${ }^{2)}$ nurulmahmudah1989@gmail.com
}

\begin{abstract}
Abstrak
Usaha Mikro, Kecil dan Menengah (UKM) memiliki peranan yang sangat penting bagi perekonomian Indonesia, khususnya perekonomian Kota Tegal, karena perkembangan UMKM di Kota Tegal meningkatkan daya serap tenaga kerja yang paling tinggi dibandingkan dengan unit usaha lainnya. Penelitian ini bertujuan untuk menganalisis penerapan akuntansi pada UMKM di Kota Tegal dan untuk mengetahui apakah UMKM di Kota Tegal sudah menyusun laporan keuangan sesuai dengan Standar Akuntansi Keuangan Entitas Tanpa Akuntabilitas Publik (SAK ETAP). Sampel penelitian ini adalah UMKM di kota Tegal yang diambil dengan teknik purposive sample. Metode pengumpulan data dalam penelitian ini mengggunakan metode observasi dengan kuesioner dan wawancara langsung dengan responden. Penelitian ini menggunakan teknik analisis deskriptif untuk mengetahui penerapan akuntansi dalam penyusunan laporan keuangan UMKM di Kota Tegal. Hasil penelitian menunjukkan bahwa penerapan akuntansi yang dilakukan oleh para pelaku UMKM di Kota Tegal masih sangat sederhana dan para pelaku UMKM di Kota Tegal belum menyusun laporan keuangan sesuai dengan SAK ETAP disebabkan karena kurangnya pengetahuan para pelaku UMKM mengenai SAK ETAP.
\end{abstract}

Kata Kunci: SAK ETAP, UMKM

Abstract

Small and Medium Enterprises (SMEs) have a very important role for the economy of Indonesia, especially the economy of Tegal City, because the development of SMEs in Tegal City increases the absorption of the highest labor force compared with other business units. This study aims to analyze the application of accounting at SMEs in Tegal City and to determine whether SMEs in Tegal City have prepared financial statements in accordance with Financial Accounting Standards Entities Without Public Accountabulity (SAK ETAP). The sample of this research is SMEs in Tegal city taken by purposive sample technique. Methods of data collection in this study used the method of observation with questionnaires and direct interviews with respondents. This study uses descriptive analysis techniques to determine the application of accounting in the preparation of financial statements of SMEs in the City of Tegal. The results showed that the implementation of accounting conducted by the perpetrators of SMEs in the city of Tegal is still very simple and the perpetrators of SMEs in the city of Tegal has not prepared financial statements in accordance with SAK ETAP due to lack of knowledge of SMEs regarding SAK ETAP.

Keywords: SAK ETAP, SMEs

\section{Pendahuluan}

Usaha Mikro, Kecil dan Menengah (UMKM) memiliki peranan yang sangat penting bagi perekonomian Indonesia, khususnya perekonomian Kota Tegal karena perkembangan UMKM di Kota Tegal meningkatkan daya serap tenaga kerja yang paling tinggi dibandingkan dengan unit usaha lainnya (Dinas Perindag, Koperasi dan UKM Kota Tegal,
2015). Melihat vitalnya perkembangan UMKM dalam menciptakan lapangan pekerjaan serta memberikan kontribusi penting dalam ekspor dan perdagangan, pemerintah Kota Tegal maupun pihak swasta memberikan beberapa dukungan salah satunya adalah dukungan finansial untuk mendapatkan kredit dari Bank atau Lembaga Keuangan lainnya. 
Dukungan pemerintah Indonesia untuk membantu permodalan UMKM adalah melalui Kredit Usaha Rakyat (KUR) yang diharapkan dapat menjadi solusi pembiayaan modal UMKM. Menurut Kim dan Elias (2008) laporan keuangan merupakan salah satu pertimbangan penting dalam pengambilan keputusan kredit. Melihat kondisi tersebut maka UMKM harus mampu menyajikan laporan keuangan agar dapat memperoleh pembiayaan kredit. Selain itu, penyusunan laporan keuangan merupakan hal yang penting karena dengan adanya pembukuan maka UMKM dapat mengetahui perkembangan dan kesehatan usahanya. Namun, kondisi di lapangan menunjukkan bahwa masih banyak UMKM yang belum menerapkan akuntansi yang memadai. Menurut informasi yang dikutip dalam Press Release kegiatan Ikatan Akuntan Indonesia (IAI) pada tanggal 16 Juni 2016, mayoritas UMKM di Indonesia sulit mendapatkan pembiayaan dari perbankan dan sumber pendanaan lainnya karena UMKM tidak memiliki laporan keuangan yang memadai dan sesuai dengan standar yang berlaku di industri keuangan. Padahal UMKM memiliki kontribusi cukup besar terhadap pertumbuhan ekonomi dan menyerap 97 persen tenaga kerja produktif.

Melihat pentingnya penerapan akuntansi bagi UMKM maka IAI selaku organisasi profesi sekaligus sebagai badan penyusun Standar Akuntansi Keuangan (SAK) melalui Dewan Standar Akuntansi Keuangan (DSAK) menyusun standar akuntansi yang sesuai dengan karakteristik UMKM. Pada tahun 2009, DSAK telah mengesahkan SAK ETAP (Entitas Tanpa Akuntabilitas Punlik) dan standar ini berlaku efektif per 1 Januari 2011. SAK ETAP merupakan standar akuntansi untuk entitas yang tidak memiliki akuntabilitas kepada publik. Diharapkan dengan adanya SAK ETAP perusahaan kecil dan menengah mampu menyusun laporan keuangannya untuk mendapatkan dana dan pengembangan usaha. Namun, standar ini masih dirasa sulit untuk diterapkan oleh UMKM sehingga IAI menyiapkan Standar Akuntansi Keuangan Entitas Mikro, Kecil Menengan (SAK EMKM) yang telah disahkan pada tanggal 24 Oktober 2016 dan rencananya akan berlaku efektif per 1 Januari 2018.

Masyarakat Kota Tegal cukup dikenal sebagai masyarakat yang memiliki jiwa wirausaha dan kreativitas yang tinggi. Hal ini ditandai dengan banyaknya unit usaha yang berkembang dan mampu menembus pasar nasional. Menurut data pemerintah Kota Tegal yang dikutip dalam Rencana Pembangunan Jangka Panjang Daerah (RPJPD) Kota Tegal, UMKM di Kota Tegal terus meningkat dari tahun ke tahun dan usaha ini merupakan usaha yang mampu bertahan dalam kondisi krisis ekonomi. Dari hasil survey awal diperoleh informasi bahwa pelaku UMKM di Kota Tegal belum memiliki pengetahuan tentang akuntansi dan pencatatan keuangan yang dilakukan masih sangat sederhana. Sehingga peneliti tertarik untuk mengkaji lebih dalam tentang penerapan akuntansi dan kesesuaiannya dengan SAK ETAP pada UMKM Kota Tegal. Objek penelitian ini adalah UMKM yang berada di wilayah Tegal dengan kriteria tertentu.

\section{Tinjauan Pustaka}

\section{Standar Akuntansi Keuangan Entitas Tanpa Akuntabilitas Publik (SAK ETAP)}

Indonesia memiliki standar akuntansi yang berlaku umum yang disebut Standar Akuntansi Keuangan (SAK). SAK di Indonesia disusun oleh Ikatan Akuntan Indonesia (IAI) melalui Dewan Standar Akuntansi Keuangan (DSAK). IAI adalah organisasi profesi yang mewadahi para akuntan di Indonesia dan memiliki peran dalam penyusunan SAK.

SAK merupakan pedoman dalam peyusunan dan penyajian laporan keuangan.IAI telah menerbitkan Standar Akuntansi Keuangan untuk Entitas Tanpa Akuntabilitas Publik (SAK ETAP). Dengan adanya SAK ETAP maka perusahaan kecil seperti UKM tidak perlu membuat laporan keuangan dengan menggunakan PSAK umum yang berlaku. Didalam beberapa hal SAK-ETAP memberikan banyak kemudahan untuk perusahaan dibandingkan dengan PSAK dengan ketentuan pelaporan yang lebih kompleks.

Sesuai dengan ruang lingkup SAK-ETAP maka standar ini dimaksudkan untuk digunakan oleh entitas tanpa akuntabilitas publik. Entitas tanpa akuntabilitas publik yang dimaksud adalah entitas yang tidak memiliki akuntabilitas publik signifikan dan tidak menerbitkan laporan keuangan untuk tujuan umum (general purposes statement) bagi pengguna eksternal. Contoh pengguna eksternal adalah pemilik yang tidak terlibat langsung dalam pengelolaan usaha, kreditur, dan lembaga pemeringkat kredit.

SAK ETAP bertujuan untuk menciptakan fleksibilitas dalam penerapannya dan diharapkan memberi kemudahan akses ETAP kepada pendanaan dari perbankan. SAK ETAP merupakan SAK yang berdiri sendiri dan tidak mengacu pada SAK Umum, sebagian besar menggunakan konsep biaya historis; mengatur transaksi yang dilakukan oleh ETAP; bentuk pengaturan yang lebih sederhana dalam hal perlakuan akuntansi dan relatif tidak berubah selama beberapa tahun (www.iaiglobal.or.id). 


\section{Usaha Mikro, Kecil dan Menengah (UMKM)}

Berikut ini merupakan definisi Usaha Mikro, Kecil dan Menengah (UMKM) menurut UndangUndang Republik Indonesia Nomor 20 Tahun 2008:

1. Usaha Mikro adalah usaha produktif milik orang perorangan dan/atau badan usaha perorangan yang memnuhi kriteria Usaha Mikro.

2. Usaha Kecil adalah usaha ekonomi produktif yang berdiri sendiri, yang dilakukan oleh orang perorangan atau badan usaha yang bukan merupakan anak perusahan atau bukan cabang perusahaan yang dimiliki, dikuasai atau menjadi bagian baik langsung maupun tidak langsung dari Usaha Menengah atau Usaha Besar yang memenuhi kriteria Usaha Kecil.

3. Usaha Menengah adalah usaha ekonomi produktif yang berdiri sendiri yang dilakukan oleh orang perorangan atau badan usaha yang bukan merupakan adak perusahaan atau cabang perusahaan yang dimiliki, dikuasai atau menjadi bagian baik langsung maupun tidak langsung dengan Usaha Kecil atau Besar dengan jumlah kekayaan bersih atau hasil penjualan tahunan.

Kriteria Usaha Mikro, Kecil dan Menengah (UMKM) menurut UU Nomor 20 tahun 2008 adalah sebagai berikut:

1. Kriteria Usaha Mikro

a. Kekayaan bersih paling banyak Rp 50.000.000,00 - lima puluh juta rupiah, tidak termasuk tanah dan bangunan tempat usaha; atau

b. Hasil penjualan tahunan paling banyak $\mathrm{Rp}$ 300.000.000,00

2. Kriteria Usaha Kecil

a. Memiliki kekayaan bersih lebih dari Rp 50.000.000,00 - Rp 500.000.000,00, tidak termasuk tanah dan bangunan tempat usaha; atau

b. Memiliki hasil penjualan tahunan lebih dari Rp 300.000.000,00 - Rp 2.500.000.000,00.

3. Kriteria Usaha Menengah

a. Kekayaan bersih lebih dari Rp 500.000.000,00 Rp. 10.000.000.000,00, tidak termasuk tanah dan bangunan tempat usaha; atau

b. Hasil penjualan tahunan lebih dari $\mathrm{Rp}$ 2.500.000.000,00 -50.000.000.000,00

\section{Laporan Keuangan}

Laporan keuangan entitas yang disajikan berdasarkan SAK ETAP meliputi:

1. Neraca

2. Laporan Laba-Rugi

3. Laporan Perubahan Ekuitas

4. Laporan Arus Kas

5. Catatan Atas Laporan Keuangan (CALK) yang berisi ringkasan kebikakan akuntansi yang signifikan dan informasi penjelasan lainnya.

\section{Metode Penelitian}

Penelitian ini merupakan penelitian deskriptif dengan menggunakan pendekatan kualitatif dan kuantitatif untuk memberikan ulasan yang diperoleh melalui kuesioner dan wawancara dengan responden penelitian. Pendekatan penelitian deskriptif dalam penelitian ini hanya sebatas membuat deskripsi tentang fenomena di lapangan mengenai penerapan akuntansi dan kesesuaiannya dengan SAK ETAP pada UMKM di Kota Tegal.

Populasi dalam penelitian ini adalah UMKM yang ada di Kota Tegal. Banyaknya UMKM di Kota Tegal serta adanya ketidakpastian jumlah UMKM di Kota Tegal, maka peneliti mengambil sampel penelitian dengan teknik purposive sample yaitu merupakan teknik pengambilan sampel berdasarkan pertimbangan-pertimbangan tertentu sesuai dengan tujuan penelitian (Sugiyono, 2014). Adapun kriteria dalam pengambilan sampel adalah sebagai berikut:

1. UMKM yang berorientasi industri.

2. UMKM yang berada di wilayah Kecamatan Tegal Timur dan Kecamatan Tegal Selatan.

3. UMKM yang melakukan kegiatan penjualan secara berkelanjutan.

4. UMKM yang memiliki omset Rp10,000,000 Rp25,000,000 per bulan.

5. UMKM yang telah melakukan kegiatan Akuntansi.

Berdasarkan kriteria pengambilan sampel di atas diperoleh jumlah responden lebih kurang sebanyak 541 responden. Teknik pengambilan sampel yang digunakan adalah purposive sample, kemudian diambil sebagian sampel berdasarkan sample size calculator www.raosoft.com dengan pertimbangan nilai margin of error 5\%, level of confidence $95 \%$ dan respon yang diharapkan $95 \%$, maka diperoleh sampel dalam penelitian ini adalah sebanyak 65 UMKM. Teknik ini dilakukan karena keterbatasan waktu, tenaga, dan dana sehingga tidak dapat mengambil sampel yang besar dan jauh.

Teknik pengumpulan data yang digunakan dalam penelitian ini adalah melalui observasi yaitu dengan cara peninjauan langsung pada objek penelitian dengan membagikan kuesioner dan wawancara terhadap responden. Kuesioner yang diberikan kepada responden berupa daftar pertanyaan tertutup dan terbuka yang bertujuan untuk mengetahui pemahaman akuntansi dan penyusunan laporan keuangan UMKM. Berikut ini merupakan indikator yang digunakan dalam menyusun kuesioner penelitian:

1. Pengetahuan dasar akuntansi dan Standar Akuntansi

2. Pengumpulan bukti transaksi

3. Pencatatan kegiatan usaha 
4. Penyusunan laporan keuangan

5. Penggunaan software akuntansi

6. Kendala dalam menyusun laporan keuangan

\section{Hasil dan Pembahasan \\ Hasil Penelitian}

Penelitian ini dilakukan untuk menganalisis penerapan akuntansi pada pelaku Usaha Kecil, Mikro dan Menengah (UMKM) di Kota Tegal serta kesesuaiannya dengan Standar Akuntansi Keuangan Entitas Tanpa Akuntabilitas Publik (SAK-ETAP). Untuk mengkaji penerapan akuntansi dan keseuaiannya dengan SAK ETAP diperoleh informasi dari hasil tabulasi data primer berupa kuesioner. Berikut ini merupakan hasil analisis kuesioner penelitian:

1. Pertanyaan Tentang Kemampuan dan Pengetahuan Dasar Akuntansi

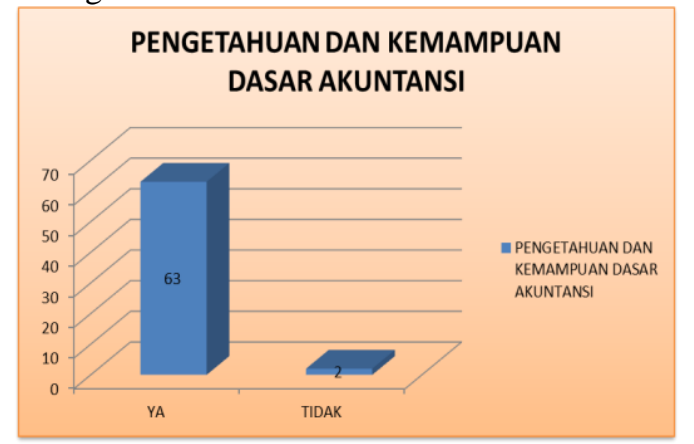

Gambar 1 Pertanyaan Tentang Pengetahuan dan Kemampuan Dasar Akuntansi

Gambar 1 di atas menunjukkan bahwa jawaban responden yang menjawab Ya sebanyak 97\% dan yang menjawab Tidak sebanyak 3\%, berarti mayoritas pelaku UMKM memiliki kemampuan dan pengetahuan dasar akuntansi.

2. Pertanyaan Tentang Pengumpulan Bukti Transaksi

Hasil jawaban responden pelaku UMKM menunjukkan bahwa mayoritas pelaku UMKM telah melakukan pengumpulan bukti transaksi. Hal ini dapat dilihat dari responden yang menjawab Ya sebanyak 38\% dan yang menjawab Tidak sebanyak $27 \%$, dapat dilihat pada Gambar 2 dibawah ini:

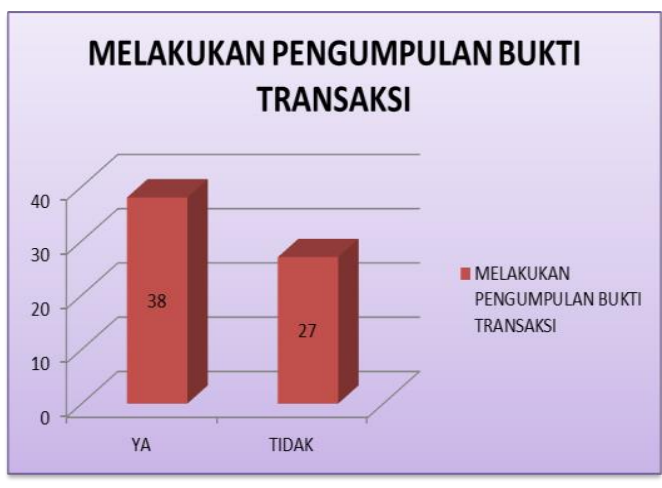

Gambar 2 Pertanyaan Tentang Pengumpulan Bukti Transaksi

3. Pertanyaan Tentang Catatan Kegiatan Usaha

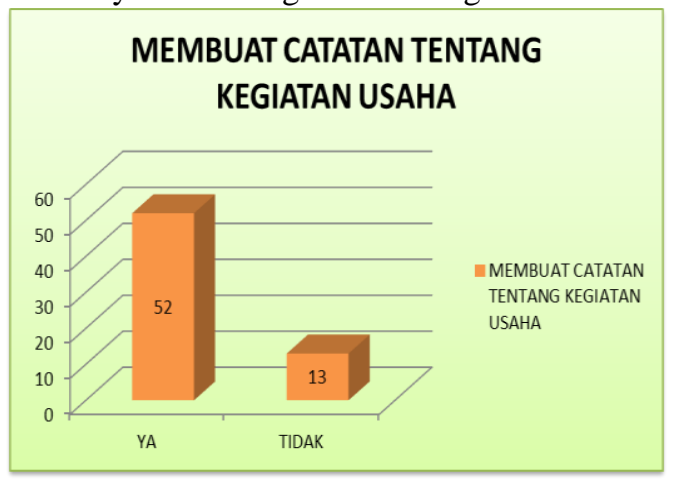

Gambar 3 Pertanyaan Tentang Catatan Kegiatan Usaha

Gambar 3 di atas menunjukkan bahwa jawaban responden yang menjawab Ya sebanyak $80 \%$ dan yang menjawab Tidak sebanyak 20\%, berarti bahwa mayoritas pelaku UMKM melakukan pencatatan mengenai kegiatan usaha. Pencatatan yang dilakukan terutama yang berkaitan dengan penerimaan dan pengeluaran kas.

\section{Pertanyaan Tentang Membuat Jurnal}

Hasil jawaban responden tentang membuat jurnal menunjukkan bahwa pelaku UMKM yang membuat jurnal lebih sedikit, hal ini dapat dilihat dari jawaban responden sebanyak $20 \%$ menjawab ya dan $80 \%$ menjawab tidak, dapat dilihat pada Gambar 4 dibawah ini: 


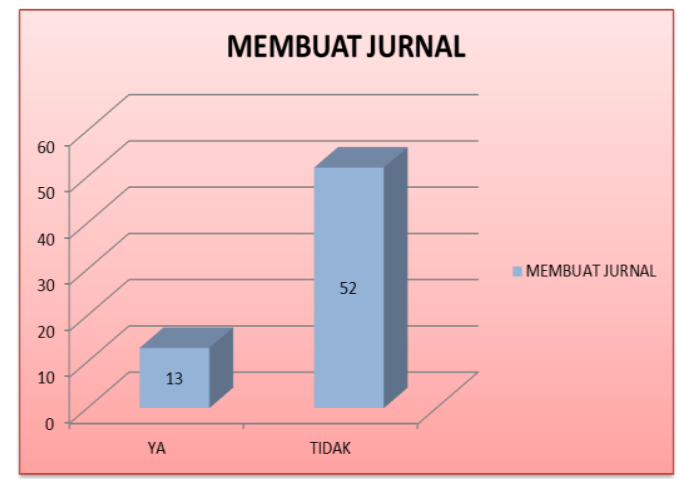

Gambar 4 Pertanyaan Tentang Membuat Jurnal

5. Pertanyaan Tentang Membuat Buku Besar

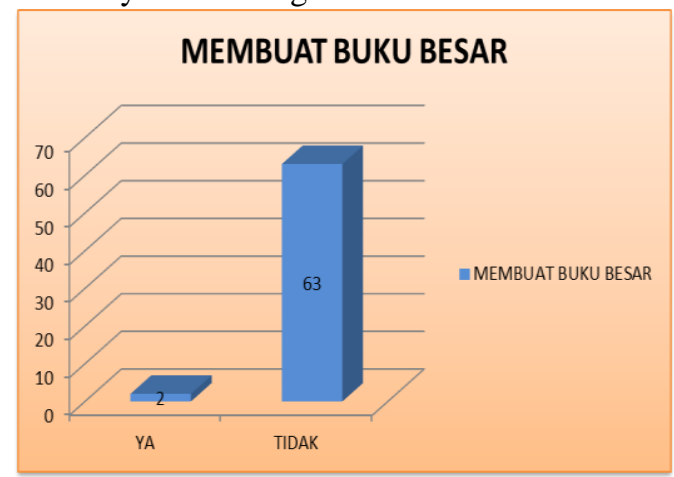

Gambar 5 Pertanyaan Tentang Membuat Buku Besar

Gambar 5 di atas menunjukkan hasil jawaban responden pelaku UMKM menunjukkan bahwa sebagian besar pelaku UMKM tidak membuat buku besar, hal ini dapat dilihat dari responden yang menjawab Ya sebanyak 97\% dan responden yang menjawab Tidak sebanyak 3\%.

6. Pertanyaan Tentang Membedakaan Keuangan Perusahaan dan Keuangan Pribadi

Hasil jawaban responden pelaku UMKM menunjukkan bahwa sebagian besar pelaku UMKM sudah membedakan antara keuangan perusahaan dan pribadi, hal ini dapat dilihat dari responden yang menjawab Ya sebanyak $60 \%$ dan Tidak sebanyak $40 \%$ yang tergambar pada gambar dibawah ini:

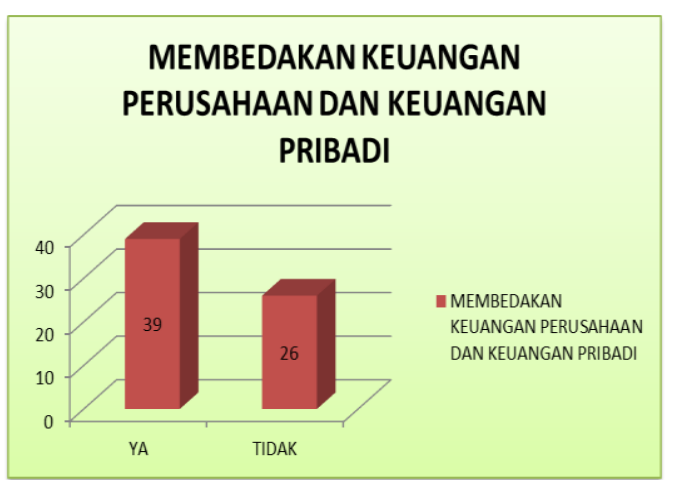

Gambar 6 Pertanyaan Tentang Membedakan antara Keuangan Perusahaan dan Keuangan Pribadi

7. Pertanyaan Tentang Menyusun Laporan Keuangan Usaha

Hasil jawaban responden pelaku UMKM menunjukkan bahwa sebagian besar pelaku UMKM sudah membedakan antara keuangan perusahaan dan pribadi, yaitu yang menjawab Ya sebanyak $75 \%$ dan Tidak sebanyak 25\%. Pelaku UMKM yang menyusun Laporan Keuangan sebagian besar mengisi Laporan yang disusun adalah Laporan Laba Rugi Sederhana dan Pemasukan/Pengeluaran Kas. Hal tersebut dapat dilihat pada gambar di bawah ini:

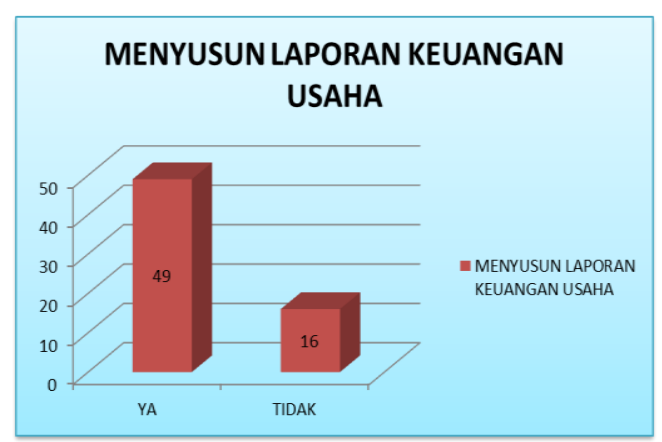

Gambar 7 Pertanyaan Tentang Menyusun Laporan Keuangan Usaha

\section{Pertanyaan Tentang Penggunaan Software Akuntansi}

Hasil jawaban responden pelaku UMKM dalam hal penggunaan software menunjukkan bahwa penggunaan software akuntansi didominasi oleh jawaban tidak, hal ini dapat dilihat dari jawaban responden yang menjawab Ya sebanyak 5\% dan responden yang menjawab Tidak sebanyak $95 \%$ yang tergambar pada gambabar di bawah ini: 


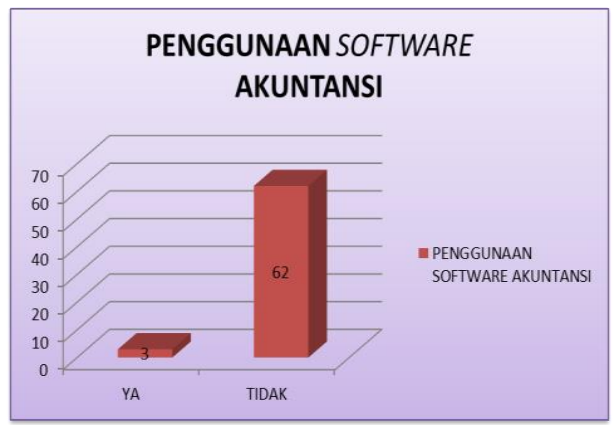

Gambar 8 Pertanyaan Tentang Penggunaan Software Akuntansi

9. Pertanyaan Tentang Kendala dalam Penyusunan Laporan Keuangan

Jawaban responden tentang kendala dalam menyusun laporan keuangan menunjukkan bahwa banyak pelaku UMKM yang memiliki kendala dalam menyusun laporan keuanganr, hal ini dapat dilihat dari jawaban responden sebanyak $43 \%$ menjawab ya dan $34 \%$ menjawab tidak. Kendala yang sering dialami adalah kerumitan dalam menyusun laporan keuangan. Berikut ini merupakan grafik jawaban responden tentang kendala dalam penyusunan laporan keuangan:

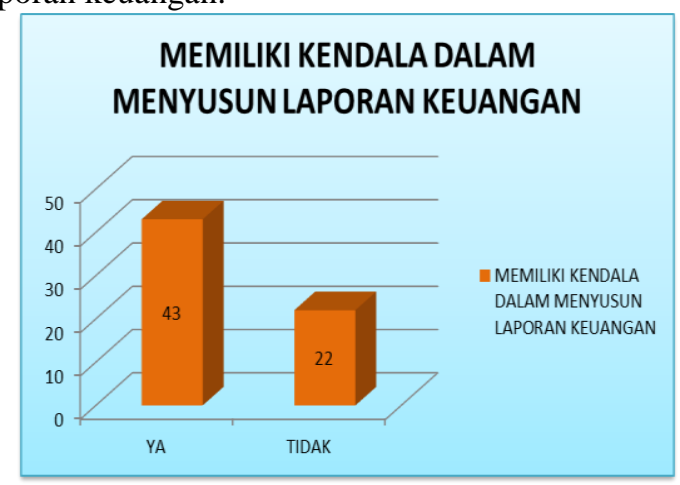

Gambar 9 Pertanyaan Tentang Kendala dalam Penyusunan Laporan Kuangan

10. Pertanyaan Tentang Pentingnya Menyusun Laporan Keuangan

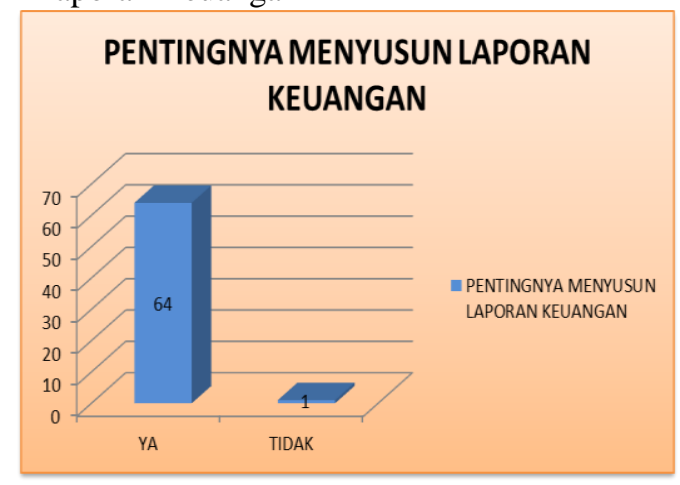

Gambar 10 Pertanyaan Tentang Pentingnya Penyusunan Laporan Kuangan

Gambar 10 di atas menunjukkan bahwa jawaban responden tentang pertanyaan mengenai pentingnya menyusun laporan keuangan menunjukkan sebagian besar pelaku UMKM menyadari pentingnya menyusun laporan keuangan demi keberlamgsungan usaha, hal ini dapat dilihat dari jawaban responden sebanyak $98 \%$ menjawab ya dan $2 \%$ menjawab tidak.

\section{Pertanyan Tentang Pengetahuan Tentang SAK ETAP}

Hasil jawaban responden pelaku UMKM menunjukkan bahwa sebagian besar pelaku UMKM tidak memiliki pengetahuan tentang SAK ETAP, hal ini dapat dilihat dari jawaban responden yang menjawab Ya sebanyak 5\% dan yang menjawab Tidak sebanyak $95 \%$.

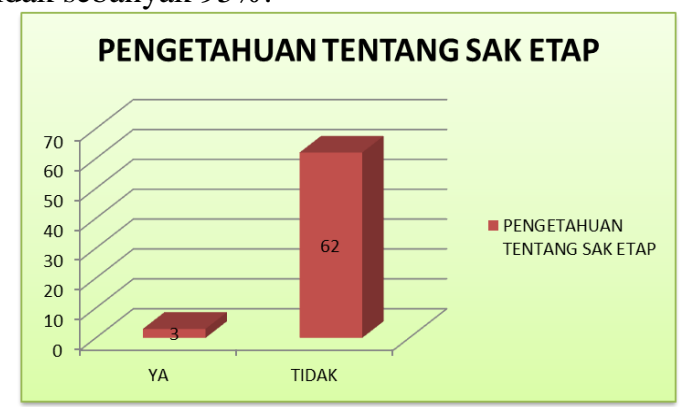

Gambar 11 Pertanyaan Tentang Pengetahuan SAK ETAP

12. Pertanyaan Tentang Pernah Mendapatkan Informasi Tentang SAK ETAP

Hasil jawaban responden pelaku UMKM menunjukkan bahwa sebagian besar pelaku UMKM belum pernah mendapatkan informasi tentang SAK ETAP, hal ini dapat dilihat dari jawaban responden yang menjawab Ya sebanyak $6 \%$ dan yang menjawab Tidak sebanyak $94 \%$. Hal ini dapat dilihat pada gambar 12 di bawah ini:

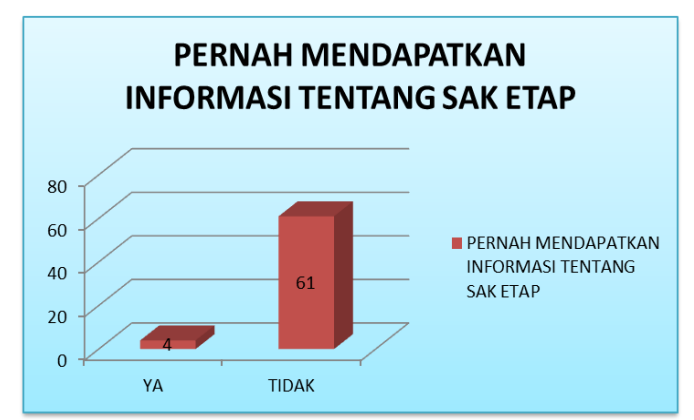

Gambar 12 Pertanyaan Tentang Mendapatkan Informasi Tentang SAK ETAP 
13. Pertanyaan Tentang Pemahaman Tentang Isi SAK ETAP

Hasil jawaban responden pelaku UMKM menunjukkan bahwa sebagian besar pelaku UMKM belum faham tentang SAK ETAP, hal ini dapat dilihat dari jawaban responden yang menjawab Ya sebanyak 3\% dan yang menjawab Tidak sebanyak 97\%. Jawaban responden tentang pemahaman mengenai isi SAK ETAP dapat dilihat pada gambar di bawah ini:

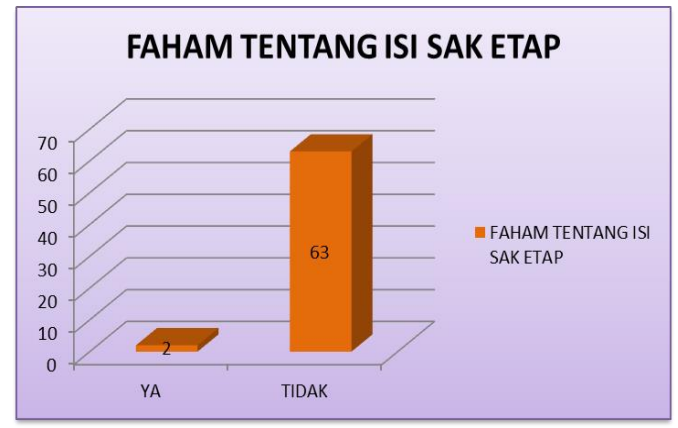

Gambar 13 Pertanyaan Tentang Pemahaman Isi SAK ETAP

\section{Pertanyaan Tentang Penerapan SAK ETAP}

Hasil jawaban responden pelaku UMKM menunjukkan bahwa seluruh responden pelaku UMKM belum menerapkan SAK ETAP, hal ini dapat dilihat dari jawaban responden 100\% Tidak.

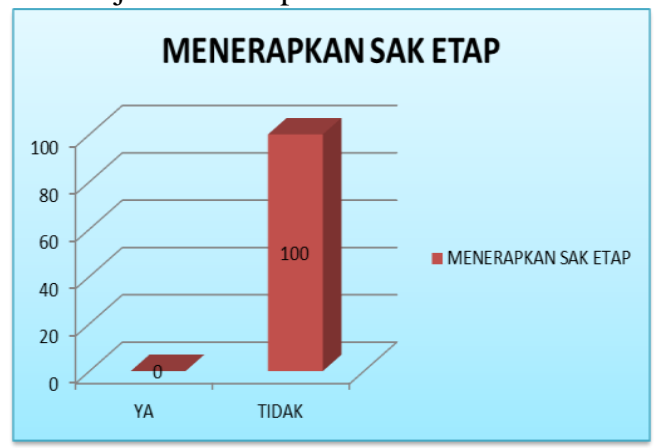

Gambar 14 Pertanyaan Tentang Penerapan SAK ETAP

15. Pertanyaan Tentang Mendapatkan Informasi Menganai SAK EMKM

Hasil jawaban responden pelaku UMKM menunjukkan bahwa seluruh responden pelaku UMKM belum pernah mendapatkan informasi tentang SAK EMKM, hal ini dapat dilihat dari jawaban responden $100 \%$ Tidak.

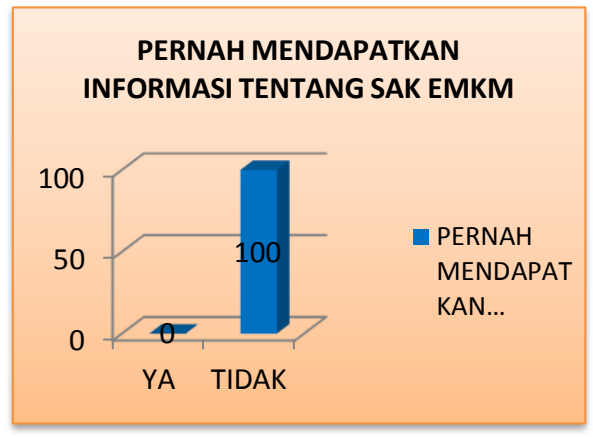

Gambar 15 Pertanyaan Tentang Mendapatkan Informasi Mengenai SAK EMKM

\section{Pembahasan}

Penelitian ini dilakukan untuk mengetahui penerapan akuntansi yang dilakukan oleh pelaku UMKM di Kota Tegal serta menganalisis apakan para pelaku UMKM di Kota Tegal sudah menyusun laporan keuangan sesuai dengan SAK ETAP. Untuk mengetahui penerapan SAK ETAP digunakan alat ukur kuesioner yang mengacu pada penelitian Saragih dan Surikayanti (2015).

Responden pelaku UMKM pada penelitian ini dibatasi pada pelaku UMKM yang bergerak di bidang industry makanan dan minuman, 65 responden dalam penelitian ini menjawab kuesioner berdasarkan pada keadaan yang terjadi pada. Berdasarkan hasil analisis kuesioner dapat dipahami bahwa para pelaku UMKM sangat menyadari pentingnya penyusunan laporan keuangan untuk perkemabangan usaha namun para pelaku UMKM masih kurang memahami tentang akuntansi dan penyusunan laporan keuangan sesuai dengan standard yang berlaku. Para pelaku UMKM menganggap bahwa pemyusunan laporan keuangan terlalu rumit.

Penerapan akuntansi yang dilakukan hanya sebatas pada pencatatan transaksi secara manual sekedar untuk mengetahui keluar masuknya kas dan laba yang diperoleh dalam kegiatan usaha, masih belum melakukan penerapan akuntansi sesuai dengan SAK ETAP karena kurangnya pemahaman para pelaku UMKM mengenai SAK ETAP. Berdasarkan informasi yang diperoleh dari hasil penelitian belum ada sosialisasi atau pelatihan yang berkaitan dengan SAK ETAP maupun SAK EMKM yang recananya mulai diterapkan pada 1 Januari 2018.

\section{KESIMPULAN DAN SARAN Kesumpulan}

Berdasarkan hasil penelitian yang telah diuraikan, maka dapat disimpulkan sebagai berikut: 
1. Penerapan akuntansi yang dilakukan oleh UMKM di Kota Tegal masih sangan sederhana yaitu hanya melakukan pencatatan mengenai keluar masuk kas dan peyusunan laporan laba rugi sederhana, bahkan ada beberapa pelaku UMKM yang tidak mengumpulkan bukti transaksi dan tidak melakukan pencatatan keuangan terkait dengan kegiatan usaha,

2. Penerapan akuntansi pada UMKM di Kota Tegal belum sesuai dengan SAK ETAP. Hal tersebut disebabkan karena kurangnya pemahaman mengenai SAK ETAP karena berdasarkan hasil wawancara belum ada sosialisasi maupun pelatihan dari pihak pemerintah maupun lembaga mengenai pemahaman SAK ETAP dan pentingnya penyusunan laporan keuangan sesuai dengan SAK ETAP.

\section{Saran}

Saran yang dapat diberikan dari hasil penelitian ini untuk penelitian selanjutnya adalah:

1. Melihat besarnya manfaat yang diperoleh dari penerapan akuntansi sesuai dengan standar yang telah ditetapkan, kepada para pelaku UMKM agar mulai menerapkan akuntansi sesuai dengan standar yang telah ditetapkan. Hal ini tentunya membutuhkan dukungan dari pemerintah maupun pihak yang berkepentingan baik berupa pembinaan maupun pelatihan.

2. Perlu adanya pengawasan atau aturan yang mengatur disertai dengan pendampingan agar ke depannya para pelaku UMKM dapat menyusun laporan keuangan sesuai dengan standar yang ditetapkan.

\section{DAFTAR PUSTAKA}

Ikatan Akuntan Indonesia. 2009. Standar Akuntansi Keuangan Entitas Tanpa Akuntabilitas Publik. Jakarta

Kim, Neung J dan Elias, Rafik Z. 2008. Financial Statements, Attestation Level and Lending Decision by Small Banks. Los Angeles: California State University.

Saragih, Fitriani dan Surikayanti. 2015. Analisis Penerapan Akuntansi dan Kesesuaiannya dengan SAK ETAP pada UKM Medan Perjuangan. Universitas Padang

Sugiono. 2014. Metodologi Penelitian Bisnis. Bandung: Alfabeta
Undang-Undang Republik Indonesia No 20 Tahun 2008 Tentang Usaha Mikro, Kecil dan Menengah. 